\title{
PROGRAM PENALARAN ISLAM INDONESIA DAN GERAKAN KONTRA-RADIKALISME
}

\author{
Ali Mas'ud, Saiful Jazil, Taufiq Subty, Muhammad Fahmi \\ (UIN Sunan Ampel Surabaya)
}

\begin{abstract}
Abstrak:
Artikel ini mendeskripsikan urgensi pelaksanaan program penalaran Islam Indonesia (PPII) sebagai penguatan materi PAI yang rahmatan lil 'alamin dan gerakan kontra radikalisme di UIN Sunan Ampel Surabaya. Data dikumpulkan dengan observasi, wawancara, dan dokumentasi. Hasil penelitian menunjukkan bahwa PPII membangun landasan keislaman berdasarkan Teologi Islam Kontekstual, Ekspresi Sufistik, Hukum Islam Kontesktual, Metodologi Hukum Islam, dan Genealogi Peradaban Islam Indonesia. Dengan demikian, perilaku Islam rahmatan lil 'alamin, akhlaqul karimah, dan nalar keislaman dapat terinternalisasi ke dalam disiplin keilmuan yang dipelajari mahasiswa. Melihat geliat gerakan keagamaan Islam yang radikal semakin berani menampilkan diri di publik, PPII menempati peran penting dalam gerakan kontra radikalisme. Materimateri dalam PPII sinergis dengan materi PAI dengan pendekatan penalaran rasional-empiris yang secara epistemologis identik dengan pendekatan Burhani.
\end{abstract}

Kata Kunci: Program Penalaran Islam Indonesia; Gerakan Kontra Radikalisme; Nalar Keislaman; Kajian Rasional-Empiris. 


\begin{abstract}
:
This article dscribes the importance of Indonesian Islam Reasoning Program (PPII) as the supplement of Islamic Education (PAI) materials bringing peace for the universe and counter radicalism movement in UIN Sunan Ampel Surabaya. Data was collected through observation, intervoews, and documentation. Findings shows that PPII established Islamic foundation based upon contextual Islamic theology, Sufism expression, contextual Islamic law, and genealogy of Islamic civilization in Indonesia. Therefore, peace Islamic attitudes, highest endeavor, and Islamic reasoning can be internalized into disciplines that students take. Observing more visible radical Islamic movement in public sphere, PPII takes important position in countering radicalism. Materials in PPII are synergic to Islamic Education materials with rational-empirical reasoning, which is epistemologically aligned with Burhani approach.
\end{abstract}

\title{
Keywords: Indonesian Islam Reasoning Program; Contra-Radicalism Movement; Islamic Reasoning; Rational-Empirical Study.
}

\section{A. Pendahuluan}

Dalam pelaksanaan "Program Penalaran Islam Indonesia (PPII)" di Universitas Islam Negeri (UIN) Sunan Ampel, terdapat hal-hal menarik yang ingin dikaji, antara lain bagaimana keberhasilan pencapaian program tersebut dengan desain awal yang direncanakan. Program penalaran Islam Indonesia di UIN Sunan Ampel relatif baru (mulai tahun 2014), sehingga perlu dilihat bagaimana kendala-kendala yang dihadapi dan nilai-nilai profesionalitas yang telah dimiliki dalam pelaksanaan kegiatan belajar mengajarnya. Perlu juga dikaitkan,substansi materi yang ada dengan gerakan kontra radikalisme dan spirit materi Pendidikan Agama Islam (PAI) yang rahmatan lil 'alamin (kasih sayang bagi penghuni alam semesta).

Desain awal dari pelaksanaan program penalaran Islam Indonesia adalah untuk meningkatkan pemahaman mahasiswa terhadap praktik-praktik Islam yang bersifat kontekstual di Indonesia. Manajemen UIN Sunan Ampel ingin membekali peserta didiknya dengan kurikulum keilmuan yang berbasiskan penalaran Islami. Ini dilakukan sebagai wujud tindak lanjut berubahnya IAIN menjadi UIN yang berakibat pada latar belakang pendidikan agama mahasiswa yang semakin beragam di UIN Sunan Ampel.

Di UIN Sunan Ampel, dalam rangka membentuk kurikulum yang berbasiskan penalaran Islami, sebelum dipraktikkan program penalaran Islam Indonesia, diawali dengan penyelenggaraan workshop penyusunan silabus dan program penalaran keislaman bagi puluhan dosen dan personil Lembaga 
Penjamin Mutu (LPM) UIN Sunan Ampel khususnya para pemangku mata kuliah ilmu-ilmu keislaman. ${ }^{1}$

Kurikulum dengan penalaran keislaman, menurut Abdul Mujib, berkaitan erat dengan dua macam kajian dalam Islam, yaitu Islam sebagai doktrin dan Islam sebagai peradaban. Dalam dimensi Islam sebagai doktrin, ia tidak menerima segala macam model penalaran, bersifat mutlak, dan tidak membuka pintu ijtihad. Sederhananya, sekiranya ada bagian yang tidak sesuai dengan sains, itu tidak akan megubah keimanan. Sedangkan dalam dimensi Islam sebagai peradaban, memungkinkan untuk menerima multi-model penalaran, relatiftentatif, serta bersifat terbuka. Dalam hal ini Islam terbuka pada kritik, dan memungkinkan untuk dilakukan ijtihad. ${ }^{2}$

Transformasi penalaran keislaman penting untuk diberikan kepada mahasiswa baik dengan metode-metode filsafat Barat (ontologis, epistemologis, dan aksiologis); maupun dengan model-model penalaran keislaman seperti pengetahuan bayani (idealis), burhani (rasionalis), dan 'irfani (intuitif). ${ }^{3}$ Penting juga memberikan materi tentang mistisisme Islam (tasawuf) dan posisinya dalam jalur nalar keislaman. Tasawuf mampu disertakan dalam berbagai bidang kajian, karena tidak mungkin mengkaji sebuah ilmu tanpa ilmu yang lain. Penting juga mengajarkan kepada mahasiswa materi-materi keislaman kontekstual yang terkait dengan praktik keislaman di Indonesia.

Praktik keislaman Indonesia kental dengan nuansa moderat dan toleran. Adnan Anwar menyatakan, ajaran Islam di Indonesia telah banyak menginspirasi negara lain dalam membangun hubungan antar-agama ataupun hubungan antara agama dan negara. Islam moderat-toleran-rahmatan lil 'alamin yang berkembang di Indonesia, terbukti mampu membangun konstruksi antar-agama dalam perspektif Negara Kesatuan Republik Indonesia (NKRI), bukan negara Islam, meski mayoritas (sekitar 80 persen) penduduk negara ini beragama Islam. ${ }^{4}$

Ajaran Islam Indonesia mampu membangun suatu sistem solidaritas antar-agama dan suatu sistem perlindungan terhadap minoritas, sehingga dapat duduk bersama dan berdialog dengan sesama. Fakta itulah yang membuat

\footnotetext{
${ }^{1}$ Workshop kurikulum berbasis penalaran Islami dilakukan di ruang sidang rektorat UIN Sunan Ampel Surabaya pada hari Senin, 28-30 September 2015, dan diprakarsai oleh Lembaga Penjamin Mutu (LPM) UIN Sunan Ampel Surabaya, Diakses pada 23 Maret 2017, http://www.uinsby.ac.id/news/id/12419/kembangkan-kurikulum-berbasis-penalaranislami

2 "Kurikulum Berbasis Penalaran Islami," Abdul Mujib, UIN Surabaya News, , Diakses pada 23 Maret 2017, http://www.uinsby.ac.id/news/id/12419/kembangkan-kurikulum-berbasispenalaran-islami

${ }^{3}$ Mujib, Kembangkan Kurikulum Berbasis Penalaran.

4 "Peneliti LP3ES Islam Indonesia," Adnan Anwar, Peneliti dari Lembaga Penelitian, Pendidikan, dan Penerangan Ekonomi dan Sosial (LP3ES), Diakses pada 23 Maret 2017, http://www.antaranews.com/berita/617040/peneliti-lp3es-islam-indonesiamenginspirasi-negara-lain
} 
Ali Mas'ud, et. al.

banyak negara terinspirasi dan ingin belajar Islam moderat dari Indonesia untuk membangun perdamaian (peace development) di negara masing-masing.

Dewasa ini, di forum-forum pertemuan internasional ulama, baik yang diselenggarakan NU atau lembaga lain, hampir seluruh perwakilan negara Timur Tengah dan Eropa selalu hadir. Hal itu menunjukkan bahwa ajaran Islam Indonesia menarik untuk dipelajari. Bahkan, atas permintaan banyak negara di Timur Tengah, NU (bagian dari Islam Indonesia) sudah membuka cabang di beberapa negara seperti Afghanistan, India, dan Pakistan, juga beberapa negara di Afrika Utara. Itu fakta bahwa mereka benar-benar ingin meniru ajaran Islam Indonesia dalam memelihara kerukunan dan kedamaian hidup bernegara. ${ }^{5}$

Indonesia dengan keragaman yang dimiliki sudah mempraktikkan diri sebagai negara darussalam atau negara yang aman dan itu menjadi modal untuk membangun peradaban. Oleh karena itu, kelompok-kelompok radikal seharusnya tidak terus menerus menyerang dan menyebarkan propaganda negatif di Indonesia, apalagi bermimpi mendirikan negara Islam di negara ini. Kalau negara lain saja betah dan mau belajar kepada Indonesia, kenapa justru orang Indonesia sendiri yang mempermasalahkan hal tersebut.

Berangkat dari pemaparan di atas, menjadi penting untuk melaksanakan program penalaran Islam Indonesia, demi mengantisipasi dan menanggulangi tumbuh suburnya kelompok-kelompok radikal dalam Islam. Berkembangnya kelompok radikal antara lain disebabkan karena pemahaman keagamaan yang dangkal dan leterlek. Pelaksanaan program penalaran Islam Indonesia (PPII) di UIN Sunan Ampel dilakukan dalam rangka memberikan pemahaman keislaman yang kontekstual kepada mahasiswa. PPII ini kemudian menjadi spirit gerakan kontra radikalisme, dan juga memperkuat materi Pendidikan Agama Islam (PAI) yang rahmatan lil 'alamin di UIN Sunan Ampel Surabaya.

\section{B. Urgensi Penalaran dalam Islam}

Berbicara tentang penalaran dalam Islam, menarik untuk meminjam teori Mohammad Abed Al-Jabiri yang membagi model penalaran dalam Islam menjadi tiga (3) kategori, yaitu: Bayani, Burhani dan Irfani. Bayani dalam bahasa Arab berarti penjelasan (exsplanation). Arti asal katanya adalah menyingkap dan menjelaskan sesuatu, yaitu menjelaskan maksud suatu pembicaraan dengan menggunakan lafadz yang paling baik (komunikatif). Para ahli ushul fiqh memberikan pengertian, bahwa bayani adalah upaya menyingkap makna dari suatu pembicaraan (kalam) serta menjelaskan secara terinci hal-hal yang tersembunyi dari pembicaraan tersebut kepada para mukallaf. Artinya bisa

\footnotetext{
${ }^{5} \mathrm{NU}$ identik dengan ajaran Islam yang moderat, sehingga ketika ingin mendalami ajaran Islam yang moderat, yang banyak diingat adalah ideology Nahdhatul Ulama (NU). Adnan Anwar, "Peneliti LP3ES."
} 
disebut sebagai upaya mengeluarkan suatu ungkapan dari keraguan menjadi jelas. ${ }^{6}$

Bayani adalah metode pemikiran khas Arab yang menekankan otoritas teks (nash), secara langsung atau tidak langsung, dan dijustifikasikan oleh akal kebahasaan yang digali lewat referensi (istidlal). Secara langsung artinya memahami teks sebagai pengetahuan jadi dan langsung mengaplikasikannya tanpa perlu pemikiran; secara tidak langsung berarti memahami teks sebagai pengetahuan mentah sehingga perlu tafsir dan penalaran. Meski demikian, hal ini tidak berarti akal atau rasio bisa bebas menentukan makna dan maksudnya, tetapi tetap harus bersandar pada teks. Dalam bayani, rasio dianggap tidak mampu memberikan pengetahuan kecuali disandarkan pada teks. Dalam perspektif keagamaan, sasaran bidik metode bayani adalah aspek eksoterik (syariat). ${ }^{7}$

Al-Jabiri memaknai al-bayan secara etimologis, dengan mengacu kepada kamus Lisan al-Arab karya Ibn Mandzur, yang di dalamnya tersedia materimateri bahasa Arab sejak permulaan masa tadwin, yang masih mempunyai makna asli yang belum tercampuri pengertian lain, karena dari makna asli tersebut akan diketahui watak dan situasi yang mengitarinya. ${ }^{8}$ Arti bayan sebagai al-fashl wa infishal (memisahkan dan terpisah) dan al-dhuhur wa alidhhar (jelas dan penjelasan). ${ }^{9}$ Keempat pengertian tersebut dapat diklasifikasikan menjadi dua kelompok, yaitu al-bayan sebagai metodologi, yang berarti pemisahan dan penjelasan; dan al-bayan sebagai pandangan hidup, yang berarti keterpisahan dan jelas. ${ }^{10}$

Sementara itu, secara terminologi, bayani mempunyai dua arti, yaitu: (1) sebagai aturan-aturan penafsiran wacana (qawanin tafsir al-khithabi), dan (2) syarat-syarat memproduksi wacana (syuruth intaj al-khithabi). Berbeda dengan makna etimologi yang telah ada sejak awal peradaban Islam, makna-makna terminologis ini baru lahir belakangan, yaitu pada masa kodifikasi (tadwin). ${ }^{11}$

Perkembangan makna bayani dari makna tradisionalnya kepada maknanya yang baru, yakni sebagai epistomologi keilmuan ini seiring dengan perkembangan tradisi Arab-Islam. Dalam hal ini dari budaya lisan dan riwayat menuju budaya tulis dan nalar atau menurut Jabiri, dari proses ketidaksadaran atau tidak direncanakan (al-la'i) menuju pada kondisi disadari (al-wa'i), atau

\footnotetext{
${ }^{6}$ Mohammad Muslih, Filsafat Ilmu; Kajian Atas Aumsi Dasar, Paradigma dan Kerangka Teori Ilmu Pengetahuan (Yogyakarta: Belukar, 2004), 181.

${ }^{7}$ Khudori Soleh, Filsafat Islam; Dari Klasik Hingga Kontemporer (Yogyakarta: Ar-Ruzz Media, 2013), 237.

${ }^{8}$ Muslih, Filsafat Ilmu, 181.

${ }^{9}$ Soleh, Filsafat Islam, 238.

${ }^{10}$ Ahmad Hasan Ridwan, Dasar-dasar Epistemologi Islam (Bandung: Pustaka Setia, 2011), 335.

11 Ridwan, Dasar-dasar Epistimologi Islam, 238.
} 
Ali Mas'ud, et. al.

dengan kata lain dari budaya yang bersifat awam menuju budaya ilmiah (akademis). ${ }^{12}$

Sementara itu Burhani merupakan metode penalaran dengan pendekatan pembuktian. Di sini model pembuktiannya bersifat rasional empirik. Para filosof muslim kebanyakan memakai pendekatan penalaran dengan model burhani. Dimana mereka mengedepankan rasionalitas mereka dalam menalar ajaran Islam dan kemudian membuktikannya secara empirik. ${ }^{13}$

Sedangkan irfani berasal dari kata irfan yang dalam bahasa Arab merupakan bentuk dasar (masdar) dari kata 'arafa, yang semakna dengan ma'rifat. Dalam bahasa Arab, istilah al-'irfan berbeda dengan kata al-ilm yang menunjukkan pemerolehan objek pengetahuan (al-ma'lumat) melalui transformasi (naql) ataupun rasionalitas ('aql), sementara irfan atau ma'rifat berhubungan dengan pengalaman atau pengetahuan langsung dengan objek pengetahuan. Epistemologi ini dikembangkan dan digunakan dalam masyarakat sufi, berbeda dengan epistemologi burhani yang dikembangkan oleh para filsuf dan epistemologi bayani yang dikembangkan dan digunakan dalam keilmuankeilmuan Islam pada umumnya (ulama fiqih). ${ }^{14}$

\section{Potret Program Penalaran Islam Indonesia (PPII) di UIN Sunan Ampel}

Desain Program Penalaran Islam Indonesia (PPII) ini antara lain dapat dilihat di dalam naskah akademik penyelenggaraan PPII bagi mahasiswa prodi umum di UIN Sunan Ampel Surabaya. Diantara pertimbangan yang dijadikan dasar dalam penyelenggaraan PPII adalah Peraturan Presiden RI No. 65 Tahun 2013 tentang peralihan status IAIN menjadi UIN Sunan Ampel dalam rangka memenuhi tuntutan perkembangan ilmu pengetahuan dan proses integrasi ilmu agama Islam dengan ilmu lain serta mewujudkan sumber daya manusia yang berkualitas. Pertimbangan tersebut menunjukkan bahwa peralihan IAIN menjadi UIN Sunan Ampel berangkat dari kajian mendalam dari epistimologi keilmuan yang dibangun, yaitu paradigma integrated twin towers (menara kembar tersambung). ${ }^{15}$

Paradigma keilmuan integrated twin towers bukan memposisikan kedua tower (menara) sebagai domain keilmuan secara dikotomis. Paradigma ini justru menjadikan keduanya sebagai sebuah kesatuan dengan objek spesifik dan ciri tersendiri namun dalam perspektif fundamental sama. ${ }^{16}$ Oleh karena itu, kedua

\footnotetext{
12 Muslih, Filsafat Ilmu, 182.

${ }^{13}$ Khudori Soleh (Ed), Pemikiran Islam Kontemporer (Yogyakarta: Pustaka Pelajar, 2008).

${ }^{14}$ Soleh, Filsafat Islam, 253.

15 Tim LPM UIN Sunan Ampel, Naskah Akademik Penyelenggaraan Program Penalaran Islam Indonesia (PPII) bagi Mahasiswa Prodi Umum di Lingkungan UIN Sunan Ampel (Surabaya: tp., 2015), 1.

${ }^{16}$ Lihat juga Syaifuddin, "Komparasi Integrated Twin Tower dan Islamisasi Ilmu”, JPAI

(Surabaya: FTK UINSA, 2014).
} 
tower disatukan dengan jembatan penghubung (interconnecting bridge) melalui pengembangan tiga pilar keilmuan, yaitu: (1) penguatan ilmu-ilmu keislaman murni tapi langka, (2) integrasi ilmu-ilmu keislaman, sosial, humaniora, dan (3) pembobotan keilmuan sains dan teknologi dengan keilmuan keislaman. Jembatan ini mengisyaratkan adanya metodologi keilmuan saling mengisi dan menguatkan dan berproses sampai menemukan titik temu yang saling memberikan pencerahan. ${ }^{17}$

Dalam pada itu, salah satu tujuan UIN Sunan Ampel Surabaya adalah menyiapkan lulusan agar menjadi anggota masyarakat yang memiliki akhlaqul karimah (akhlak yang mulia), kemampuan akademik dan/atau profesional yang dapat menerapkan, mengembangkan, dan/atau menciptakan ilmu-ilmu keislaman multidisipliner, serta sains dan teknologi yang dijiwai oleh nilai-nilai keislaman. Tujuan tersebut disemangati oleh pengintegrasian disiplin keilmuan demi terciptanya tata keilmuan complementary antara ilmu-ilmu keislaman dengan sosial-humaniora, sains, dan teknologi.18 Melalui paradigma ini, UIN Sunan Ampel menjadi wadah pendidikan dengan lulusan bercorak Islami humanis-dialogis yang memadukan antara praktik dzikir dan pikir (QS. 39: 9; 3: 7), kedewasaan bersikap (QS. 39: 18; 5: 100) dan kemapanan intelektual (QS. 39: 18; 3: 190-191). Corak ini sesuai dengan tag-line yang disematkan yaitu Building Character Qualities for the Smart, Pious and Honorable Nation. ${ }^{19}$

Peralihan status dari intsitut menjadi universitas juga diiringi dengan peralihan paradigma keilmuan di dalamnya. ${ }^{20}$ Hal ini menjadikan UIN Sunan Ampel Surabaya telah membuka beberapa fakultas dan program studi baru, diantaranya Fakultas Kesehatan (FKES), Fakultas Ekonomi dan Bisnis Islam (FEBI), Fakultas Sains dan Teknologi (FSAINTEK), serta Fakultas Ilmu Sosial dan Ilmu Politik (FISIP). Prodi-prodi umum di fakultas baru, juga prodi umun di fakultas lama, harus dapat menyesuaikan diri dengan paradigma keilmuan UIN Sunan Ampel. Karenanya, peralihan status ini sekaligus memberikan tantangan, bagaimana mengawal mahasiswa prodi-prodi umum tersebut dapat mencapai

17 Tim UIN Sunan Ampel, Konsep Integrated Twin Towers UINSA Surabaya, dipresentasikan oleh Akh. Muzakki, dalam Workshop Konsorsium Dosen UIN Sunan Ampel, Lawang, 10 November 2014. Lihat juga Tim LPM UIN Sunan Ampel, Naskah Akademik Penyelenggaraan Program Penalaran Islam Indonesia (PPII), 1.

18 Tim UIN Sunan Ampel, Renstra Bisnis UIN Sunan Ampel 2014-2019 (Surabaya: Uinsa Press, 2014), 2.

19 Tim LPM UIN Sunan Ampel, Naskah Akademik Penyelenggaraan Program Penalaran Islam Indonesia (PPII), 2.

${ }^{20}$ Peralihan paradigma keilmuan yang dimaksud adalah dari deskriptif ke penalaran. Dalam bahasa lain dari epistemologi bayani ke burhani atau irfani. Epistemology bayani, burhani dan irfani banyak diteorikan oleh Muhammad Abed Al-Jabiry dalam Bunyah al-'Aql al-'Arabi (Beirut: Markaz ad-Dirasat Wahdah al-'Arabiyah, 2007), 373-377. 
Ali Mas'ud, et. al.

mutu kompetensi akademik sebagaimana disinggung dalam tujuan UIN Sunan Ampel tersebut. ${ }^{21}$

Tim UIN Sunan Ampel telah menyusun sebuah Program Penalaran 22 Islam Indonesia (PPII), guna membekali mahasiswa dari prodi-prodi umum menjadi profesional di bidang keilmuannya masing-masing dengan kompetensi nalar secara Islami. Program ini bukan dalam rangka Islamisasi pengetahuan atau ayatisasi pengetahuan, namun lebih pada bagaimana terciptanya tata keilmuan complementary antara ilmu-ilmu keislaman, sosial-humaniora, sains, teknologi. Capaian akhir kompetensi program ini adalah agar lulusan dari prodiprodi umum tersebut menjadi figur intelektual profesional yang rahmatan lil 'alamin. ${ }^{23}$

Program ini sekaligus untuk menjawab temuan berbagai riset tentang fenomena kecenderungan mahasiswa prodi-prodi umum di beberapa perguruan tinggi Islam yang telah beralih status menjadi UIN terjebak dalam nalar-nalar radikalisme dan bahkan aksi terorisme. Dengan demikian, penyelenggaraan PPII merupakan agenda yang sangat penting, karena menjadi ciri pembeda bagi UIN Sunan Ampel dalam menyiapkan lulusannya dengan perguruan tinggi lain. ${ }^{24}$ PPII ini menjadi spirit kontra radikalisme dan penguatan materi PAI rahmatan lil ‘alamin.

Penyelenggaraan PPII yang sejalan dengan peralihan status menjadi UIN Sunan Ampel ini memerlukan dukungan total dari semua civitas akademika. Untuk itu, setiap fakultas yang memiliki prodi-prodi umum dapat serius memperhatikan keterlaksanaan mutu akademik mahasiswa sesuai dengan desain keilmuan UIN Sunan Ampel. Selain itu, dalam membantu perencanaan dan kontrol mutu akademik mahasiswa, maka dibentuklah Pusat Pendampingan dan Pengembangan Mutu Mahasiswa (P3M2) sesuai ORTAKER UIN Sunan Ampel

21 Tim LPM UIN Sunan Ampel, Naskah Akademik Penyelenggaraan Program Penalaran Islam Indonesia (PPII), 2.

22 Penalaran adalah suatu proses berfikir dalam menarik suatu kesimpulan yang berupa pengetahuan. Sebagai suatu kegiatan berfikir penalaran memiliki ciri-ciri tertentu. Ciri pertama adalah proses berpikir logis, dimana berpikir logis diartikan sebagai kegiatan berpikir menurut pola tertentu atau dengan kata lain menurut logika tertentu. Ciri yang kedua adalah sifat analitik dari proses berpikirnya. Sifat analitik ini merupakan konsekuensi dari adanya suatu pola berpikir tertentu. Analisis pada hakikatnya merupakan suatu kegiatan berpikir berdasarkan langkah-langkah tertentu. Lihat Jujun S. Suriasumantri, Filsafat Ilmu (Jakarta: Sinar Harapan, 1985).

${ }^{23}$ Penegasan bahwa PPII ini ditujukan untuk membekali mahasiswa dengan sikap dan perilaku Islam yang rahmatan lil 'alamin dinyatakan oleh Khoirun Ni'am (Ketua Pengembangan Standar Mutu LPM UINSA), dalam sambutannya pada acara workshop peningkatan kapasitas dosen PPII, 11-13 Juli 2017 di ruang Rektorat lama UIN Sunan Ampel Surabaya.

${ }^{24}$ Tim LPM UIN Sunan Ampel, Naskah Akademik Penyelenggaraan Program Penalaran Islam Indonesia (PPII), 3. 
tahun 2014. ${ }^{25}$ Unit ini hadir di bawah struktur organisasi Lembaga Penjaminan Mutu (LPM) untuk mengawal pelaksanaaan akademik di tingkat fakultas agar mahasiswa mampu mencapai kompetensi akademik sesuai dengan yang diharapkan. ${ }^{26}$

Kegiatan PPII dilakukan dalam bentuk pendampingan. Pendampingan ini bersifat kolaboratif, yaitu berupa kegiatan tatap muka langsung (TM) atau tidak langsung untuk memberikan materi, model, problem solving, studi kasus, studi visit, dan lain-lain berdasarkan kreatifitas pendamping, yang totalnya ekuivalen dengan 20 sks yang berkaitan dengan penalaran keislaman Indonesia. ${ }^{27}$

Pendampingan wajib diikuti oleh seluruh mahasiswa dari prodi-prodi umum di fakultas-fakultas baru seperti Fakultas Sains dan Teknologi (FSAINTEK), Fakultas Kesehatan (FKES), Fakultas Ekonomi dan Bisnis Islam (FEBI), serta Fakultas Ilmu Sosial dan Ilmu Politik (FISIP), juga di Fakultas lama yang mempunyai prodi umum seperti Prodi Ilmu Komunikasi di Fakultas Dakwah, Prodi Sastra Inggris di Fakultas Adab, serta Prodi Pendidikan Bahasa Inggris dan Prodi Matematika di FTK, juga prodi umum lain yang sedang dalam proses perijinannya. Pendampingan diselenggarakan oleh sebuah Tim Pengelola tingkat Fakultas di bawah koordinasi Pusat Pendampingan dan Pengembangan Mutu (P3M) Mahasiswa LPM UIN Sunan Ampel Surabaya.

Mengenai wajibnya PPII untuk mahasiswa prodi umum ini sebagaimana ditegaskan oleh Muhammad Thohir:

"Terkait dengan semangat mahasiswa, memang belum seratus persen. Dalam pelaksanaan perkuliahan PPII, ada yang mahasiswa hanya masuk kuliah separuhnya, ada yang tidak sampai separuh, bahkan ada yang tidak pernah masuk sama sekali. Ini terkait dengan kesadaran mahasiswa yang terkesan masih menganggap bahwa kuliah PPII tidak wajib diikuti. Padahal pihak pimpinan sudah mewajibkan untuk mahasiswa prodi umum untuk mengikuti kuliah PPII, karena sertifikat kelulusan PPII menjadi prasyarat untuk ujian skripsi dan kelulusan atau wisuda. Memang penekanan kurang dilakukan oleh pimpinan di tingkat fakultas dan prodi, sehingga mahasiswa kurang menganggap penting kuliah ppii, padahal ini menjadi syarat untuk bisa ujian skripsi. Meski sanksinya jelas tapi kurang ada penekanan, maka kebijakan apapun kurang bergayung sambut di lapangan." 28

Bentuk tagihan dari penyelenggaraan PPII adalah berupa produk esai. Penulisan Esai Ilmiah merupakan tugas projek di akhir setiap materi yang

\footnotetext{
25 PMA RI No. 8 Tahun 2014 tentang Ortaker UIN Sunan Ampel Surabaya, Pasal 77, Ayat 1 (c).

${ }^{26}$ PMA RI, Pasal 77, Ayat 4.

27 Penalaran keislaman Indonesia dimaksudkan untuk menalar praktik-praktik Islam di Indonesia, dan mahasiswa diharapkan mampu memiliki sikap dan perilaku keislaman yang khas Indonesia; Islam Nusantara, Islam berbasis kearifan local; yang berorientasi pada praktik Islam yang toleran, moderat, cinta damai dan rahmah bagi alam semesta. Konsep khas Islam Indonesia sejalan dengan ide pribumisasi Islam sebagaimana yang pernah digagas Gus Dur tahun 1980-an.

${ }^{28}$ Muhammad Thohir (Ketua P3M2 LPM UINSA), Wawancara pada 15 Juni 2017.
} 
Ali Mas'ud, et. al.

diberikan saat pendampingan PPII. Projek Esai Ilmiah Penalaran Islam tersebut dapat diarahkan sebagai esai ilmiah pendek atau bahkan esai panjang untuk bahan jurnal ilmiah. Projek esai ilmiah ini dapat diganti dengan produk-produk hasil pendampingan lain, seperti ceramah ilmiah dan karya kreatif ilmiah lain.

Bentuk penghargaan, keberhasilan atau prestasi mahasiswa PPII diwujudkan dalam bentuk sertifikat. Penyelesaian dan kelulusan semua materi pendampingan merupakan syarat wajib bagi mahasiswa untuk memperoleh Sertifikat Kelulusan dalam PPII. Sertifikat PPII akan diberikan pada semester 7 setelah mahasiswa menyelesaikan materi pendampingan terakhir. Sertifikat PPII merupakan salah satu syarat bagi mahasiswa untuk mengikuti ujian skripsi. Dengan demikian, apabila belum lulus dari PPII, maka mahasiswa belum bisa mengikuti ujian skripsi.

Mengenai kompetensi lulusan mahasiswa PPII adalah Mahasiswa prodi umum UIN Sunan Ampel yang mampu memiliki penalaran keislaman yang rahmatan lil 'alamin. Kompetensi inti yang harus dimiliki oleh lulusan mahasiswa PPII terdiri dari: (1) Kompetensi Inti-1 (KI-1): untuk keseimbangan dzikir dan pikir, mengacu pada al-Qur'an surat ke-39 ayat 9; juga surat ke-3 ayat 7. (2) Kompetensi Inti-2 (KI-2): untuk kedewasaan bersikap, mengacu pada al-Qur'an surat ke-39 ayat 18; juga surat ke-5 ayat 100. (3) Kompetensi Inti-3 (KI-3): untuk kemapanan intelektual, baik secara konsep, metodologis dan praktik, mengacu pada al-Qur'an surat ke-39 ayat 18; juga surat ke-3 ayat 190-191.29

Dari ketiga Kompetensi Inti (KI) di atas, maka lulusan UIN Sunan Ampel diharapkan setelah mengikuti PPII, mereka mampu menjadi pribadi yang beriman, berakhlakul karimah dan profesional dalam menerapkan dan mengembangkan ilmu pengetahuan yang dijiwai oleh nilai-nilai keislaman. Berdasarkan kompetensi inti di atas, maka disusun matakuliah dan alokasi waktu yang disesuaikan dengan schedule perkuliahan reguler. Susunan matakuliah yang merupakan hasil beberapa kali rapat Tim Perumus dari anggota Konsorsium dosen di LPM adalah: (1) Teologi Islam Kontekstual diberikan pada semester III dengan bobot 4 sks; (2) Ekspresi Sufistik diberikan pada semester IV dengan bobot 4 sks; (3) Hukum Islam Kontekstual diberikan pada semester V dengan bobot 4 sks; (4) Metode Penalaran Hukum Islam diberikan pada semester VI dengan bobot 4 sks; (5) Genealogi Peradaban Islam Indonesia diberikan pada semester VII dengan bobot 4 sks.

Mahasiswa yang mengikuti Program Penalaran Islam Indonesia didampingi dan dibimbing oleh seorang dosen di masing-masing kelasnya. Para dosen diusulkan oleh Tim Pengelola Fakultas kepada Pusat Pendampingan dan Pengembangan Mutu Mahasiswa (P3M2) Lembaga Penjaminan Mutu UIN Sunan Ampel Surabaya. Proses rekruitmen mahasiswa oleh P3M dilakukan

${ }^{29}$ Tim LPM UIN Sunan Ampel, Naskah Akademik Penyelenggaraan Program Penalaran Islam Indonesia (PPII), 5. 
bekerjasama dengan konsorsium dosen di bidang ilmu terkait sesuai dengan homebase masing-masing dosen.

Program Penalaran Islam Indonesia (PPII) diselenggarakan dengan menggunakan collaborative learning dari berbagai pendekatan dan metode dalam proses pendampingannya, seperti, pendekatan kebermaknaan (meaningfull learning), contextual teaching and learning, pembelajaran gotong royong (cooperative), active learning, dan lain-lain. ${ }^{30}$ Semua metode pendampingan yang dipilih oleh dosen diarahkan pada pencapaian bagaimana mahasiswa mampu memiliki penalaran Islam Indonesia sesuai dengan capaian pembelajaran (CP) masing-masing materi pendampingan yang diikuti.

Pendampingan dinilai berdasarkan kriteria umumnya, seperti: (1). Kehadiran 10\%; (2). UTS 30\%; (3). Tugas 20\%; (4). UAS 40\%. Instrumen penilaian dalam proses perkuliahan sangat bergantung pada bagaimana pilihan metode pendampingan yang digunakan oleh dosen pengampu. Penilaian pendampingan disesuaikan dengan pendekatan/ metode yang dipilih oleh dosen yang mengedepankan aspek kognitif atau penalaran tingkat lanjut (high order thinking), bukan sebatas menguji pengetahuan semata.

Calon peserta Program Penalaran Islam Indonesia adalah mahasiswa Prodi Umum yang telah menyelesaikan perkuliahan di semester I dan II. Mahasiswa melakukan pendaftaran dibantu oleh Ketua Prodi dan Tim Pengelola UIN Sunan Ampel Surabaya di setiap awal semester. Dalam tata kelola selanjutnya, proses pendaftaran mahasiswa PPII dalam tiap semesternya, diharapkan dapat disinergikan dengan aplikasi SIAKAD. Mahasiswa yang tidak terdaftar tidak dapat mengikuti perkuliahan Program Penalaran Islam Indonesia dan tidak memperoleh persyarat menerima sertifikat PPII. ${ }^{31}$

Kurikulum dengan penalaran keislaman, berkaitan erat dengan dua macam kajian dalam Islam, yaitu Islam sebagai doktrin dan Islam sebagai peradaban. Dalam dimensi Islam sebagai doktrin, ia tidak menerima segala macam model penalaran, bersifat mutlak, dan tidak membuka pintu ijtihad. Sederhananya, sekiranya ada bagian yang tidak sesuai sains, itu tidak akan megubah keimanan. Sedangkan dalam dimensi Islam sebagai peradaban, memungkinkan untuk menerima multi-model penalaran, relatif-tentatif, serta bersifat terbuka. Dalam hal ini Islam terbuka pada kritik, dan memungkinkan untuk dilakukan ijtihad. 32

Penting untuk melakukan transformasi penalaran keislaman terhadap mahasiswa baik dengan metode-metode filsafat Barat; Ontologis, Epistemologis, dan Aksiologis, maupun dengan model-model penalaran keislaman seperti

${ }^{30}$ LPM UIN Sunan Ampel, Naskah Akademik, 5.

${ }^{31}$ LPM UIN Sunan Ampel, Naskah Akademik, 6.

${ }^{32}$ Mujib, Kembangkan Kurikulum, http://www.uinsby.ac.id/news/id/12419/kembangkankurikulum-berbasis-penalaran-islami 
Ali Mas'ud, et. al.

pengetahuan Bayani ${ }^{33}$ (idealis), Burhani ${ }^{34}$ (Rasionalis), dan Irfani ${ }^{35}$ (Intuitif). Di era sekarang penting juga mengkaji materi tentang mistisisme Islam (tashawwuf) dan posisinya dalam jalur nalar keislaman. Tasawuf mampu disertakan dalam berbagai bidang kajian, karena tidak mungkin dikaji sebuah ilmu tanpa ilmu yang lainnya.

\section{PPII, Materi PAI Rahmatan lil 'Alamin dan Kontra Radikalisme}

Program Penalaran Keislaman Indonesia (PPII) merupakan program pendidikan tambahan Non SKS (kookurikulier) yang wajib diikuti oleh mahasiswa prodi umum terdiri dari serangkaian matakuliah dan tugas-tugas akademik tentang penalaran Islam Indonesia yang penyelenggaraannya berada di bawah koordinasi Pusat Pendampingan dan Pengembangan Mutu (P3M) Mahasiswa di bawah Lembaga Penjaminan Mutu (LPM) UIN Sunan Ampel.

Tujuan PPII antara lain: 1. Menjadikan mahasiswa prodi umum UIN Sunan Ampel memiliki penalaran keislaman yang rahmatan lil 'alaimin; 2. Menjadikan mahasiswa mampu menjadi pribadi yang beriman, berakhlakul karimah dan profesional dalam menerapkan dan mengembangkan ilmu pengetahuan yang dijiwai oleh nilai-nilai keislaman; 3. Menjadikan mahasiswa

33 Bayani dalam bahasa Arab berarti penjelasan (exsplanation). Arti asal katanya adalah menyingkap dan menjelaskan sesuatu, yaitu menjelaskan maksud suatu pembicaraan dengan menggunakan lafadz yang paling baik (komunikatif). Para ahli ushul fiqh memberikan pengertian, bahwa bayani adalah upaya menyingkap makna dari suatu pembicaraan (kalam) serta menjelaskan secara terinci hal-hal yang tersembunyi dari pembicaraan tersebut kepada para mukallaf. Artinya bisa disebut sebagai upaya mengeluarkan suatu ungkapan dari keraguan menjadi jelas. Bayani ini model penalaran berbasis teks. Lihat Mohammad Muslih, Filsafat Ilmu; Kajian Atas Asumsi Dasar, Paradigma dan Kerangka Teori Ilmu Pengetahuan (Yogyakarta: Belukar, 2004), 181.

${ }^{34}$ Burhani berasal dari bahasa Arab, al-burhan, berarti argumen (al-hujjah) yang jelas (albayyinah; clear) dan distinc (al-fashl), yang dalam bahasa Inggris adalah demonstration, yang mempunyai akar bahasa Latin: demonstratio (berarti memberi isyarat, sifat, keterangan, dan penjelasan). Epistemologi burhani merupakan pengetahuan yang diperoleh dengan latihan rasio atau akal semata. Prinsip pengetahuan rasional dapat diterapkan pada pengalaman indera, tetapi tidak disimpulkan dari pengalaman indera. Lihat Uyoh Saduloh, Pengantar Filsafat Pendidikan (Bandung: Alfabeta, 2009), 31-32.

35 Irfani berasal dari bahasa Arab, irfan, yang merupakan bentuk dasar (masdar) dari kata 'arafa, yang semakna dengan kata ma'rifat. Dalam bahasa Arab, istilah al-'irfan berbeda dengan kata al-'ilm yang menunjukkan pemerolehan objek pengetahuan (al-ma'lumat) melalui transformasi ( $n a q l$ ) ataupun rasionalitas ('aql), sementara irfan atau ma'rifat berhubungan dengan pengalaman atau pengetahuan langsung dengan objek pengetahuan. Epistemologi ini dikembangkan dan digunakan dalam masyarakat sufi, berbeda dengan epistemologi burhani yang dikembangkan oleh para filsuf dan epistemologi bayani yang dikembangkan dan digunakan dalam keilmuan-keilmuan Islam pada umumnya. Irfani merupakan model penalaran berbasis intuisi atau hati nurani. Lihat Khudori Soleh, Filsafat Islam; Dari Klasik Hingga Kontemporer (Yogyakarta: Ar-Ruzz Media, 2013), 253. 
mampu mengintegrasikan nalar keislaman pada pengembangan disiplin keilmuan yang sedang ditempuh oleh mahasiswa. ${ }^{36}$

Menjadikan mahasiswa yang berperilaku Islam rahmatan lil 'alamin, berakhlaqul karimah, dan mampu mengintegrasikan nalar keislaman kedalam disiplin keilmuan yang ditempuh merupakan tujuan dari kegiatan PPII. Hal ini sejalan dan mendukung pencapaian tujuan daripada UIN Sunan Ampel dengan paradigma keilmuan integrated twin towers. Sebagaimana dinayatakan oleh Ibnu Anshori:

"Lulusan UINSA adalah menjadi Ulul Albab. Ulul Albab artinya: pious (taqwa), venerable (kematangan spiritual), smart (cerdas). Untuk melengkapi itu maka perlu belajar keislaman, ilmu sosial-sain teknologi, dan integrated multidisciplinary-approaches within 3 process (pengajaran, penelitian, pengabdian). ${ }^{37}$

PPII di UIN Sunan Ampel Surabaya wajib diikuti oleh seluruh mahasiswa dari prodi-prodi umum di Fakultas-fakultas baru seperti Fakultas Sains dan Teknologi (FSAINTEK), Fakultas Kesehatan (FKES), Fakultas Ekonomi dan Bisnis Islam (FEBI), serta Fakultas Ilmu Sosial dan Ilmu Politik (FISIP), juga di Fakultas lama yang mempunyai prodi umum seperti Prodi Ilmu Komunikasi di Fakultas Dakwah, Prodi Sastra Inggris di Fakultas Adab, serta Prodi Pendidikan Bahasa Inggris dan Prodi Matematika di FTK, juga prodi umum lain yang sedang dalam proses perizinan. Pendampingan dalam PPII telah diselenggarakan oleh Tim Pengelola tingkat Fakultas di bawah koordinasi Pusat Pendampingan dan Pengembangan Mutu (P3M) Mahasiswa LPM UIN Sunan Ampel.

Mengenai wajibnya mahasiswa UIN Sunan Ampel prodi-prodi umum mengikuti PPII ini juga ditegaskan oleh Syamsul Huda:

"PPII wajib diikuti oleh mahasiswa terutama mahasiswa prodi umum. Memang saat ini masih belum maksimal bahkan dalam dua semester ini tidak jalan karena tidak teranggarkan di RKAKL. Persoalan ini sudah ditangani dan diselesaikan oleh Rektor dan kedepan akan dijalankan lagi secara lebih baik dan maksimal."38

PPII bagi para mahasiswa UIN Sunan Ampel telah dilaksanakan dalam bentuk kegiatan pendampingan dengan tahapan: pra kegiatan, kegiatan dan pasca kegiatan. Pada tahap pra kegiatan, diundang pimpinan fakultas dan koordinator pelaksana PPII di tingkat fakultas, bersama tim LPM dan Warek 1.

${ }^{36}$ LPM UINSA, Dokumen Laporan Kegiatan Program Penalaran Islam Indonesia (PPII) Tahun 2016 (Surabaya: tp., 2017).

${ }^{37}$ Ibnu Anshori (Ketua LPM UINSA), Critical Review Integrated Twin Towers, Paparan dalam Workshop Peningkatan Kapasitas Dosen PPII, 11-13 Juli 2017, di Ruang Rektorat Lama UIN Sunan Ampel Surabaya.

38 Syamsul Huda (Warek 1 UINSA), Wawancara pada 16 September 2017 di hotel Royal Orchid Garden Kota Batu. 
Ali Mas'ud, et. al.

Pada tahapan ini dibahas infomasi perkembangan kebijakan, koordniasi dan persiapan pelaksanaan PPII pada setiap awal semester.

Pada tahap kegiatan, diselenggarakan pendampingan pada mahasiswa dimana para dosen memberikan materi sesuai jadwal materi dan kelas-kelas yang telah ditetapkan. Pelaskanaan PPII diselenggarakan setiap hari Senin dan Rabu pada sore hari. Pada semester genap tahun 2016, PPII dimulai pada bulan Maret sampai Juni. Sedangkan untuk semester gasal, dimulai pada September sampai Desember.

Pada tahap pasca kegiatan, para koordinator melakukan pelaporan Surat Pertanggung Jawaban (SPJ) dan dosen pendamping melakukan evaluasi hasil pendampingan pada setiap materi pendampingan yang diampunya, dan melalui koordinator PPII di masing-masing fakultas, melaporkannya ke Pusat Pendampingan dan Pengembangan Mutu Mahasiswa (P3M2) LPM UIN Sunan Ampel Surabaya. Evaluasi kegiatan PPII diselenggarakan dalam bentuk rapat bersama antara perwakilan dosen pendamping, koordinator, dan P3M2 LPM UINSA. ${ }^{39}$

Rangkaian kegiatan PPII dijadwalkan dengan mengikuti kalender akademik perkuliahan reguler. Hanya saja, dalam progress report, ternyata tidak semua fakultas dapat memulainya sesuai dengan jadwal, antara lain di Fakultas SAINTEK \& PSIKES, FEBI \& FISIP, FDK dan FAHUM. Hanya di FTK yang dapat terlaksana sesuai dengan jadwal. Hal ini karena beberapa kendala: 1. Penerapan regulasi remunerisasi yang menyebabkan banyak dosen PNS tidak bersedia menjadi dosen pendamping PPII, sehingga koordniator harus mencari para penggantinya; 2. Tempat atau kelas yang terbatas sehingga harus menunggu hasil koordinasi antar pimpinan untuk peminjaman kelas dari fakultas lain; 3 . Benturan waktu, dimana seharusnya perkuliahan reguler sudah selesai pukul 16.00 WIB, akan tetapi kenyataannya ada yang sampai pukul 17.30 WIB;40 4 . Secara umum mahasiswa FDK tidak bersedia mengikuti PPII dengan alasan mengalami kelelahan setelah kuliah reguler mulai pagi sampai sore.

Meski demikian, kegiatan PPII sudah diusahakan sesuai dengan prosedur yang telah ditetapkan. Pada saat rapat koordinasi sebelum pelaksanaan PPII yang mengundang para pimpinan fakultas, ternyata tidak semua pimpinan hadir. Akibatnya, seakan ada perbedaan persepsi tentang PPII itu sebagai hal yang tidak wajib diikuti oleh mahasiswa. Minimnya kehadiran dalam rapat koordniasi, juga mengakibatkan para koordninator seperti kurang mendapat dukungan dari pihak fakultas. Selain itu, untuk tahap pelaporan, para dosen masih banyak yang belum menuntaskan tahap akhir kegiatan, yaitu laporan kepada LPM tentang hasil evaluasi materinya yang diajarkan kepada mahasiswa.

${ }^{39}$ Nikmatul Khoiroh (Kordinator PPII FDK),Wawancara pada 12 Juli 2017.

40 LPM UINSA, Dokumen Laporan Kegiatan Program Penalaran Islam Indonesia (PPII) Tahun 2016 (Surabaya: tp., 2017). 
Dalam pada itu, rumusan silabus kegiatan PPII dilakukan oleh para dosen ahli di bidangnya. Bahkan, juga dilibatkan para pakar nasional dalam rangka membantu konsep silabus tiap materi. Dalam realisasinya, akibat banyak dosen PNS yang tidak bersedia mengajar, maka para dosen pengganti sebagian belum teridentifikasi kapasitas keislaman moderatnya. Oleh karena itu, pada tahun 2017 LPM mengadakan workshop peningkatan kapasitas dosen terkait. ${ }^{41}$

Pada masa PPII 2016-2017, kinerja Tim LPM dirasakan kurang optimal karena adanya rolling mutasi karyawan, sehingga mengakibatkan beban lebih bagi Kasubbag TU LPM, yaitu mengajari karyawan baru yang ditempatkan di LPM dengan kapasitas yang minim. LPM terutama di bagian Pusat Pendampingan dan Pengembangan Mutu Mahasiswa lebih memerankan fungsi pelaksana akademik, sehingga peran utamanya sebagai kontrol mutu akademik kurang berfungsi.

Persepsi tentang LPM sebagai control akademik dan bukan pelaksana teknis akademik itu pula yang membuat pejabat baru LPM (Dr. Ibnu Anshori, MA) berkeberatan untuk menjadi pihak pelaksana teknis PPII ini, karena semestinya LPM itu berperan sebagai pelaksana kontrol kualitas akademik, bukan pelaksana teknis akademik. Hal itu kemudian berdampak pada tidak teranggarkannya pelaksanaan PPII dalam RKAKL LPM UIN Sunan Ampel pada tahun 2017. Sehingga pada tahun ajaran 2016-2017 (Genap) dan tahun ajaran 2017-2018 (Ganjil) PPII ini tidak dilaksanakan. ${ }^{42}$

Secara rasional, PPII untuk para mahasiswa prodi umum memang sangat tepat sasaran. Namun, dalam progresnya -menurut laporan para pendampingternyata tidak semua mahasiswa di prodi umum itu minim pengetahuan dan nalar keagamaannya. Sementara pada sisi lain, sebagian mahasiswa di prodi keagamaan justru berasal dari sekolah umum yang minim pengetahuan keagamaannya. Atas dasar inilah, maka kegiataan PPII yang hanya dikonsetrasikan pada mahasiswa di prodi-prodi umum kurang ideal. Semestinya PPII ini disasarkan kepada semua mahasiswa UIN Sunan Ampel, baik prodi umum maupun prodi keagamaan, mengingat judulnya adalah penalaran, dan semua mahasiswa butuh terhadap program ini.

\footnotetext{
41 Workshop ini terealisasi pada tangal 11-13 Juli di ruang Rektorat lama UIN Sunan Ampel Surabaya. Disamping diikuti oleh Tim LPM, para koordinator dan dosen pendamping PPII, juga mendatangkan narasumber dari luar UINSA, yaitu Ustadz Naha'i (dari IAI Ibrohimy Situbondo) dan Dr. Afan Gafar (dari UGM Yogyakarta).

42 Muhammad Thohir (Ketua P3M2 LPM UINSA), Wawancara pada 15 Juni 2017. Dalam wawancara ini terlihat bahwa informan selaku Koordinator P3M2 menyayangkan kasus tidak dianggarkannya kegiatan PPII dalam RKAKL LPM UINSA Tahun 2017, sehingga membuat program ini tidak terlaksana pada tahun tersebut, padahal PPII ini menjadi program wajib bagi UINSA sebagai konsekwensi dari beralihnya status dari IAIN menjadi UIN, dan sebagai konsekwensi logis dari paradigma Integrated Twin Towers.
} 
Ali Mas'ud, et. al.

Era sekarang ini perlu untuk beragama secara rasional dengan pendekatan penalaran. Melihat geliat gerakan keagamaan Islam yang radikal semakin berani menampilkan diri di publik, maka program penalaran Islam Indonesia menjadi sesuatu yang penting sebagai gerakan kontra radikalisme dan penguatan materi PAI yang rahmatan lil 'alamin. Materi-materi dalam PPII sinergis dengan materi PAI. Di PPII, materi-materinya dikaji dengan pendekatan penalaran atau dikentalkan dengan kajian rasional-empiris. Dalam epistemologi filsafat Islam, berarti seirama dengan pendekatan Burhani.

Dengan demikian, eksistensi PPII di UIN Sunan Ampel sangat urgen. Ketidakterlaksanaan PPII mulai tahun 2017 amat disayangkan, mengingat program ini merupakan program yang sangat penting, apalagi melihat fenomena gerakan keagamaan yang tidak toleran (radikal) semakin marak di negeri ini. Di era reformasi, berbagai kelompok Islam radikal (gerakan yang tidak toleran terhadap perbedaan ideologi) semakin naik daun, seiring dengan proses transisi demokrasi yang semakin terseok-seok. Di tengah kondisi masyarakat yang kurang kondusif, serta pecahnya konflik keagamaan di beberapa daerah, telah memberikan peluang bagi kelompok-kelompok Islam berhaluan radikal memainkan peran dominan dalam isu-isu nasional. Di era ini kelompok Islam radikal (non mainstream) semakin berani menampakkan diri ke tengah ruang publik. 43

Kelompok-kelompok Islam radikal yang mempunyai misi Islamisasi tatanan kenegeraan, berupaya mentransformasi sistem demokrasi kenegaraan. Gerakan demi gerakan digencarkan bedasarkan situasi yang ada pada transisi tersebut hanya seperti suara keras yang sulit didengar. Gerakan (aksi-aksi teror) yang dilakukan oleh kelompok Islam dapat disimpulkan hanya membawa kesan negatif bagi umat Islam sendiri. Masyarakat tidak buta atau tuli ketika melihat atau mendengar kelompok yang mengatasnamakan Islam melakukan gerakan yang dinilai melebihi batas kemanusiaan.

PPII diantaranya bertujuan untuk mengajarkan dan menyebarkan ajaran Islam yang toleran, moderat, cinta damai, dan rahmatan lil 'alamin. Apabila kegiatan PPII ini secara intensif dijalankan, maka secara -langsung atau tidakakan dapat melakukan gerakan deradikalisasi (kontra radikalisme) di negeri ini. Menguatnya gerakan radikalisme dengan tuntutan pemberlakuan syariat Islam dan lahirnya Peraturan Daerah (Perda) syariat Islam di beberapa daerah, merupakan salah satu persoalan penting yang banyak mendapatkan perhatian masyarakat.

Dalam perspektif ilmu sosial-politik, istilah radikalisme umumnya memang memiliki makna yang dapat dikaitkan dengan sikap atau tindakan ketidakpuasan seseorang atau kelompok terhadap keberadaan status dan

${ }^{43}$ A. Rubaidi, Radikalisme Islam, Nahdlatul Ulama dan Masa Depan Moderatisme Islam di Indonesia (Surabaya: Pengurus Wilayah Nahdlatul Ulama Jawa Timur, 2007), 80. 
tuntutan terhadap sesuatu yang sudah mapan, agar terjadi perubahan secara mendasar terhadap persoalan tertentu. Istilah radikalisme ini sering juga dipersamakan dengan gerakan sosial yang bersifat ekstrim kiri (terutama terhadap komunisme-marxisme), akan tetapi dalam perkembangannya istilah tersebut juga dilekatkan dengan sebutan gerakan ekstrim kanan (misalnya terhadap fasisme dan nazisme). Dalam pengertian terakhir ini istilah radikalisme keagamaan digolongkan sebagai gerakan sosial yang bersifat ekstrim kanan. Istilah ekstrim kiri dan ekstrim kanan inilah yang pada masa lalu sering digunakan oleh banyak orang untuk menyebut kelompok gerakan-gerakan yang bersifat radikal. ${ }^{4}$

Gerakan radikalisme Islam tidak dapat dipisahkan dari gerakan fundamentalisme Islam. Keduanya merupakan gerakan keislaman yang sehati seirama. Begitu juga dengan fundamentalisme Islam, term dan konsep radikalisme Islam bukan berasal dari rahim Islam, akan tetapi merupakan produk impor dari Barat. Hingga detik ini, belum ada kesepakatan di antara pemerhati Islam mengenai istilah yang tepat untuk menggambarkan gerakan radikalisme Islam. Fazlur Rahman memberikan label pada gerakan ini dengan sebutan gerakan neorevivalisme atau neofundamentalisme, yakni sebuah gerakan yang mempunyai semangat anti Barat. ${ }^{45}$

Dalam perkembanganya, terdapat dua bentuk berbeda dari gerakan Islam radikal di Indonesia. Pertama, gerakan Islam radikal yang masih berada dalam habitatnya. Beberapa diantaranya adalah, Hizbut Tahrir Indonesia (HTI) yang sudah dicabut izinnya di Indonesia oleh Pemerintahan Jokowi per 29 Juli 2017, Tarbiyah-Ikhwanul Musliminan dan Gerakan Salafi-Wahabi. Kedua, gerakan Islam radikal yang sudah bermetamorfosis, meskipun secara ideologis sangat berkesesuaian dengan gerakan Islam radikal transnasional di Timur Tengah. Beberapa contoh dapat disebut, misalnya, Front Pembela Islam (FPI), Laskar Jihad (LJ), Majelis Mujahidin Indonesia (MMI), dan sebagainya. ${ }^{46}$

Dalam gerakannya, mereka melibatkan serangkaian aktivisme keagamaan yang melibatkan kelompok-kelompok Islam militan. Kelompok militan ini memiliki kesadaran politik yang sangat tinggi, bermusuhan dengan negara, unsur-unsur penguasanya, dan juga lembaga-lembaga negara. Antara pendukung gerakan kebangkitan yang lebih luas dengan kelompokkelompok militan terjadi hubungan yang simbiotik, dimana kelompok militan akan mudah malakukan rekrutmen anggota-anggota baru, dan mudah pula bersembunyi di balik gerakan kebangkitan Islam ketika berkonfrontasi dengan aparat penguasa. Oleh sebab itu tidak heran, gerakan kebangkitan Islam

\footnotetext{
${ }^{44}$ Nuhrison M. Nuh, "Faktor-faktor Penyebab Munculnya Faham/Gerakan Islam Radikal di Indonesia", Jurnal Multikultural dan Multi Religius, Vol. 8 No.31 (September 2009), 37.

45 Imam Mostofa, "Terorisme: Antara Aksi dan Reaksi", Religia, Vol. 15 No.1 (April 2012), 74.

${ }^{46}$ Rubaidi, Radikalisme Islam, 81-91.
} 
Ali Mas'ud, et. al.

dianggap sebagai suatu rangkaian kesatuan yang dinamis antara spiritualisme pasif-apolitis dengan militansi dan radikalisme.

Keragaman kelompok ini menarik untuk dicermati, terutama dari aspek pola gerakannya masing-masing. Hetrogenitas sebuah kelompok dalam sosiologi biasanya dianggap sebuah keuntungan bagi kelompok yang lain, perpecahan di antara mereka dianggap oleh sebuah kelompok yang besar atau yang memegang status quo sebagai anugerah untuk menghambat kelompok lain. Dalam kenyataannya, secara tidak langsung heterogenitas kelompok Islam radikal menjadi anugerah bagi kelompok ini untuk tetap dapat eksis.

Melihat fenomena gerakan radikalisme yang semakin bervariasi, maka menjadi sangat penting PPII ini diintensifkan bagi seluruh mahasiswa UIN Sunan Ampel. Hal ini dimaksudkan agar alumni UIN Sunan Ampel selamat dari pengaruh gerakan radikalisme dan tetap konsisten dalam menyebarkan ajaran Islam yang rahmatan lil 'alamin (Islam yang mengajak bukan mengejek, Islam yang merangkul bukan memukul, Islam yang merawat bukan merusak, dan sejenisnya). ${ }^{47}$

PPII sangat penting karena membekali mahasiswa dengan ajaran Islam (materi PAI) yang rahmatan lil 'alamin, menghargai budaya lokal dan mengantisipasi diri dari terilibat dalam kelompok radikalisme atau fundamentalisme Islam. Dalam rangka pemahaman yang tepat tentang Islam rahmatan lil 'alamin dalam kerangka PPII, maka perlu ada acara-acara pembinaan bagi para dosen agar betul-betul memahami desain program PPII ini dan bisa mengimplementasikannya dengan baik serta tidak salah arah; dan berjalan sesuai desainnya. ${ }^{48}$

\section{E. Daya Dukung PPII}

Diantara faktor pendukung Program Penalaran Islam Indonesia (PPII) adalah adanya kebijakan yang mewajibkan semua mahasiswa prodi umum di UIN Sunan Ampel untuk mengikuti kegiatan PPII tersebut. Kebijakan ini dikomandani oleh Warek 1 UIN Sunan Ampel. Dari Warek 1 turun ke Wadek 1 lalu ke prodi-prodi yang bersangkutan serta dibantu oleh P3M2 LPM dan Koordinator di fakultas masing-masing. Hal ini sebagaimana dinyatakan oleh Muhammad Thohir:

"Mengenai kebijakan PPII, itu ada di pimpinan, Warek 1 turun ke Wadek 1 lalu ke prodi-prodi, tetapi selama ini kesannya hanya dimulai oleh warek 1 lalu dikelola oleh P3M2 LPM, sementara Wadek 1 dan prodi terkesan tidak aktif dalam pengelolaan PPII ini. Padahal semestinya LPM itu sebagai unit yang tidak

\footnotetext{
47 Islam rahmatan lil 'alamin itu sebagaimana dicontohkan oleh Rasulullah saw ketika berdakwah. Dalam konteks Jawa -Indonesia, sebagaimana didakwahkan oleh Wali Songo.

${ }^{48}$ Karim (Dosen Pendamping PPII FISIP), Wawancara pada 12 Juli 2017.
} 
seharusnya melaksanakan program perkuliahan, tetapi hanya mengontrol mutu akademiknya saja. Ini bagian dari hal yang salah kaprah." 49

Adanya kebijakan pimpinan ini menjadi dukungan dan motivasi tersendiri dalam pelaksanaan PPII. Kebijakan ini menjadi sesuatu yang logis dari peralihan status dari IAIN menjadi UIN Sunan Ampel dengan paradigma keilmuan yang integrative, yaitu integrated twin towers. Paradigma keilmuan integrated twin towers bukan memposisikan kedua towers sebagai domain keilmuan secara dikotomis. Paradigma ini justru menjadikan keduanya sebagai sebuah kesatuan dengan objek spesifik dan ciri tersendiri dalam perspektif fundamental sama. Paradigm integrated twin towers mengasumsikan kedua keilmuan agama dan sains sama-sama sudah mandiri dan tidak perlu digabungkan, hanya saja perlu disambungkan, dikoneksikan, didialogkan, dikomunikasikan di antara satu dengan yang lain. ${ }^{50}$

Paradigma integrated twin towers menggambarkan dua tower; tower yang satu sebagai symbol keilmuan agama, dan tower satunya sebagai symbol keilmuan umum/sains. Kemudian kedua tower itu disatukan dengan jembatan penghubung (interconnecting bridge) melalui pengembangan tiga pilar keilmuan, yaitu (1) penguatan ilmu-ilmu keislaman murni tapi langka, (2) integrasi ilmuilmu keislaman-sosial-humaniora, dan (3) pembobotan keilmuan sains dan teknologi dengan keilmuan keislaman. ${ }^{51}$ Jembatan ini mengisyaratkan adanya metodologi keilmuan saling mengisi dan menguatkan dan berproses sampai menemukan titik temu yang saling memberikan pencerahan. Dalam kerangka filsafat ilmu, ini sangat ditekankan untuk dilakukan demi menuju keilmuan yang utuh-integral-integratif. 52

Faktor pendukung berikutnya adalah materi PPII yang bersifat kontekstual dan berbasis pada penalaran. Hal ini menjadikan sesuatu yang menarik karena diasumsikan mahasiswa tidak akan jenuh dengan materi-materi keislaman yang kontekstual dan berbasis penalaran. Materi kontekstual ini dapat berupa, misalnya, kalau ada mahasiswa yang punya pekerjaan sampingan di pabrik, kemudian materi kuliahnya berupa ekspresi sufistik, maka dia bisa menerapkan sikap dan perilaku sufistik selama menjalani pekerjaan di pabrik. Atau bisa juga dikaitkan dengan spesifikasi keilmuan di prodi. Misalnya, kalau mahasiswa dari prodi saintek, lalu materi kuliah regulernya tentang teknik lingkungan, maka materi PPII yang terkait dengan ekspresi sufistik bisa

\footnotetext{
${ }^{49}$ Muhammad Thohir (Ketua P3M2 LPM UINSA), Wawancara pada 15 Juni 2017.

${ }^{50}$ Muhammad Fahmi, "Pengembangan Epistemologi Integrated Twin Towers di UIN Sunan Ampel Surabaya”, Episteme (Tulung Agung: PPs STAIN Tulung Agung, 2011).

51 Tim LPM UIN Sunan Ampel, Naskah Akademik Penyelenggaraan Program Penalaran Islam Indonesia (PPII), 1.

${ }^{52}$ Moh. Faizin, Pengembangan Epistemologi Twin Towers dalam Perspektif Filsafat Ilmu (Surabaya: Lemlit IAIN Sunan Ampel, 2012).
} 
Ali Mas'ud, et. al.

dikaitkan dengannya, yaitu bagaimana menyikapi lingkungan secara arif dan bijaksana. Jadi memang perlu pendampingan dan pembinaan lagi bagi dosendosen pengampu mata kuliah PPII, agar tercapai satu persepsi dalam pembelajaran. ${ }^{53}$

Materi kontekstual adalah materi-materi yang aktual dan berkaitan dengan permasalahan keagamaan kontemporer yang terjadi di masyarakat. Model penalaran yang tepat dalam menyikapi persoalan-persoalan keagamaan yang bersifat kontemporer adalah penalaran dengan epistemologi burhani, yaitu menalar berdasarkan rasio terhadap fenomena dan realitas yang terjadi. Apabila dapat diaplikasikan dengan benar, maka materi-materi kuliah dalam PPII ini seharusnya menjadi daya tarik tersendiri bagi mahasiswa.

Materi kontekstual juga dapat berupa praktik-praktik keislaman kontemporer yang ada di negeri ini. Praktik keislaman di negeri Indonesia misalnya bisa berupa praktik keislaman garis keras, bisa juga praktik keislaman liberal, dan juga bisa praktik keislaman moderat. Dari praktik-praktik keislaman yang ada tersebut kemudian dinalar dan mahasiswa diarahkan pada praktik keislaman yang moderat, toleran, cinta damai, menghargai budaya lokal, dan rahmatan lil 'alamin.

Pentingnya materi Islam yang kontekstual, disebabkan karena agama tidak hanya berbasis pada tekstualitas saja, tetapi harus juga berbasis pada kontekstualitas. Agama memerlukan relevansi geologis dan ekologis yang tepat. ${ }^{54}$ Dalam mengarahkan pemahaman Islam yang kontekstual, perlu membaca sumbernya secara kontekstual, berarti harus melihat asbabun nuzul dan asbabul wurud. Diantara cara mengislamkan Indonesia atau mengindonesiakan Islam adalah pada wilayah ajaran Islam yang furu', bukan ushul. Cara memahami dan mengamalkan Islam yang kontekstual adalah dengan pemahaman dan sikap, bahwa ayat selalu mengandung dua unsur, yaitu bunyi teks dan maksud teks tersebut (qawaid lughawiyah dan qawaid syar'iyah). Dalam teori usul fiqih, teks itu berfungsi untuk menunjukkan makna yang terkandung dalam teks tersebut. Dalam tujuannya, ayat diturunkan untuk kemaslahatan. Jadi harus memperhatikan unsur kemasalahatan tersebut. 55

Faktor pendukung berikutnya bagi pelaksanaann PPII ini adalah adanya sanksi bagi mahasiswa yang tidak mengikutinya, bahwa mereka tidak akan diberi sertifikat PPII jika tidak mengikuti perkuliahan PPII. Sertifikat ini menjadi syarat untuk bisa maju ujian skripsi. Memang saat ini terkesan sanksi ini berlaku

53 Muhammad Thohir (Ketua P3M2 LPM UINSA), Wawancara pada 15 Juni 2017.

${ }^{54}$ Affan Ghoffar (Dosen UGM Yogyakarta), Genealogi Peradaban Islam Indonesia, Paparan dalam Workshop Peningkatan Kapasitas Dosen PPII, 11-13 Juli 2017, di Ruang Rektorat Lama UIN Sunan Ampel Surabaya.

55 Naha'i (Dosen IAI Ibrohimy Situbondo), Hukum Islam Kontekstual, Paparan dalam Workshop Peningkatan Kapasitas Dosen PPII, 11-13 Juli 2017, di Ruang Rektorat Lama UIN Sunan Ampel Surabaya. 
lunak artinya tidak ketat, tetapi suatu saat pasti akan diberlakukan secara ketat. Hal ini sebagaimana ditegaskan oleh Muhammad Thohir: "Sebenarnya sanksi untuk mahasiswa yang tidak mengikuti PPII jelas, mereka tidak akan dapat sertifikat. Mereka yang tidak punya sertifikat PPII tidak boleh maju ujian skripsi".56

Dengan demikian, faktor pendukung kegiatan PPII secara umum di UINSA adalah: adanya kebijakan yang mewajibkan semua mahasiswa prodi umum di UINSA untuk mengikuti PPII; adanya materi-materi yang kontekstual dan berbasis penalaran, dimana materi ini sangat dibutuhkan di era sekarang; adanya sanksi bagi mahasiswa yang tidak mengikuti atau tidak lulus PPII berupa tidak diberikannya sertifikat PPII kepada mereka sebagai syarat untuk ujian skripsi.

\section{F. Kendala PPII}

Dari hasil evaluasi, kegiatan PPII pada tahun 2016-2017 mengalami beberapa kendala, antara lain: 1. Mundurnya sebagian besar dosen PNS UINSA sebagai dosen pendamping PPII karena sistem penggajian remunerasi yang dirasa tidak jelas; 2. Terbatasnya kelas dan benturan jam dengan perkuliahan reguler; 3. Adanya sebagian peserta yang masih bermental apriori dan tidak aktif dalam PPII; 4. Anggaran yang terbatas di LPM,57 bahkan hilang di RKAKL tahun 2017, sehingga mulai tahun tersebut PPII tidak terealisasi; 5. Mindset penalaran berbasis kontekstual yang belum sepenuhnya dipahami oleh pendamping PPII; dan kendala-kendala yang lain.

Dalam Focus Group Discussion (FGD) penyusunan standar penelitian dan pengabdian kepada masyarakat, Ibnu Anshori menyatakan bahwa PPII saat itu (2017) tidak dilaksanakan dengan baik. Padahal kalau dilaksanakan dengan baik, itu bisa menjadi icon luar biasa di UIN Sunan Ampel. Tahun 2017 tidak jalan karena tidak ada anggaran. Ini yang tidak beres. Semestinya, karena sudah menjadi kebijakan, maka harus dilaksanakan. Pelaksanaannya harus di bawah arahan Warek 1 (Wakil Rektor Bidang Akademik). ${ }^{58}$

Penyebab tidak terlaksananya PPII pada tahun 2017, disamping karena tidak teranggarkan di RKAKL, juga karena ketua LPM saat ini ingin mengembalikan tanggung jawab pelaksanaan PPII kepada pimpinan rektorat (Warek 1); dalam artian LPM berkeberatan jika melaksanakan teknis PPII, mengingat sebenarnya bahwa LPM itu bertugas menjaga kendali mutu dan

\footnotetext{
${ }^{56}$ Muhammad Thohir (Ketua P3M2 LPM UINSA), Wawancara pada 15 Juni 2017.

57 LPM UINSA, Dokumen Laporan Kegiatan Program Penalaran Islam Indonesia (PPII) Tahun 2016 (Surabaya: tp., 2017).

58 Ibnu Anshori (Ketua LPM UINSA), komentar dalam FGD Penyusunan Standar Penelitian dan Pengabdian kepada Masyarakat, Rabu, 23-8-2017, di Gedung Twin Towers A Lantai 9.
} 
Ali Mas'ud, et. al.

melakukan monitoring akademik, bukan pelaksana akademik. Hal ini sebagaimana ungkapan Muhammad Thohir:

"Semestinya LPM itu hanya pengontrol, bukan pelaksana, sehingga untuk tahun ini (semester genap 2016/2017) PPII tidak berjalan karena pihak LPM ingin mengembalikan pelaksanaan PPII kepada unit yang semestinya, bisa pesantren, atau prodi-prodi yang bersangkutan. Apalagi anggaran untuk pelaksanaan PPII saat ini tidak ada slotnya di LPM. LPM semestinya hanya menjadi unit yang melaksanakan peningkatan SDM yang terlibat dalam pelaksanaan PPII, misalnya, memfasilitasinya dalam bentuk workshop peningkatan kapasitas dosen, dan sejenisnya." ${ }^{\prime 59}$

Kendala lain dalam pelaksanaan PPII adalah terkait dengan para pengampu mata kuliah PPII. Mindset para dosen pengampunya belum satu persepsi. Seharusnya, materi-materi yang diberikan kepada mahasiswa adalah materi-materi keagamaan yang bersifat kontekstual, bukan tekstual. Sehingga pendekatan yang diterapkan oleh dosen dalam pembelajaran semestinya model pendampingan bukan ceramah. Tetapi dalam praktiknya masih banyak dosen yang model pembelajarannya menggunakan ceramah. Ini tidak sinkron dengan desainnya. Apa bedanya dengan model pembelajaran di program reguler jika pendekatannya memakai ceramah. Dalam desainnya, materi harus bersifat kontekstual dan model pembelajarannya berupa pendampingan, sehingga kuliahnya tidak selalu harus berbentuk tatap muka, tetapi bisa berbentuk pemberian tugas proyek yang terkait dengan materi kuliah.

Bagaimanapun, PPII wajib dilaksanakan dengan pola-pola penalaran yang bersifat kontekstual. Dahulu waktu menyusun program awal PPII, namanya adalah PKI (Penalaran Keislaman Indonesia), tetapi ketika dirasa sebutan PKI itu bias, maka dirubah menjadi PPII (Program Penalaran Islam Indonesia). Memang saat ini masih debateble antara apakah PPII ini masih ditangani oleh LPM atau unit lain di UINSA. Kalau menurut ketua LPM (2017), seharusnya PPII itu ditangani unit lain semisal Pesantren. Karena LPM itu wewenangnya hanya mengontrol dan memonitor kualitas pelaksanaan program yang diselenggarakan oleh setiap unit, bukan pelaksana teknis seperti yang selama ini dilakukan dalam PPII. Jadi harus dirubah dulu kebijakannya terkait siapa yang seharusnya mengelola pelaksanaannya; jangan LPM.

LPM awalnya punya usulan bahwa sebaiknya PPII ditangani oleh unit pesantren, sayangnya pesantren juga sudah overload karena sudah menangani program penguatan keagamaan. Sehingga saat ini masih mengambang, menunggu kebijakan lanjutan dari Warek 1. Mungkin kedepan PPII ini diintegrasikan dengan program prodi yang selama ini menangani kuliah reguler.

${ }^{59}$ Muhammad Thohir (Ketua P3M2 LPM UINSA), Wawancara pada 15 Juni 2017. 
Lalu mata kuliah yang ada dimasukkan dalam siakad, sehingga mahasiswa dapat memprogramnya. ${ }^{60}$

Kendala lain dalam PPII adalah lemahnya semangat mahasiswa dalam PPII. Hal ini sangat mungkin terjadi karena kurang pahamnya mahasiswa terhadap kewajiban kuliah dalam kegiatan PPII. Untuk mengatasi lemahnya semangat mahasiswa dalam mengikuti mata kuliah PPII ini, pihak LPM perlu berlaku tegas dengan menertibkan serifikat PPII, mereka yang tidak lulus PPII tidak akan diberi sertifikat sehingga mereka tidak bisa ujian skripsi.

Idealnya memang PPII ini masuk dalam penanganan pesantren. Untuk mengantisipasi menumpuknya pekerjaan di pesantren, maka perlu ada penambahan personel di unit pesantren UIN Sunan Ampel, dan masing-masing personel harus jelas tugas dan wewenangnya. Kalaupun pesantren tidak sanggup mengatasinya karena sudah over load pekerjaannya, pengelolaan PPII bisa diintegrasikan dengan kuliah reguler dalam perencanaannya dan pemrogramannya dapat dipadukan dalam sistem melalui siakad.

LPM perlu menggerakkan dekan-dekan di fakultas agar membantu mengaktifkan PPII di masing-masing fakultasnya, tetapi LPM tidak punya garis instruktif ke dekan-dekan, jadi secara normatif, LPM tidak bisa menginstruksi dekan-dekan; yang bisa menginstruksi adalah rektorat. Di sinilah kemudian diperlukan peran aktif dari rektorat untuk ikut membantu memaksimalkan pelaksanaan PPII di UINSA.

Dari sisi mahasiswa, yang menjadi kendala bagi mereka sehingga mereka banyak yang tidak antusias mengikuti PPII adalah faktor kelelahan. Bayangkan, mereka sudah kuliah sejak pagi sampai siang, lalu sore ditambah kuliah PPII. Secara fisik dan pikiran mereka sudah merasa capek. Belum lagi mereka yang sudah kadung terikat kontrak kerja di waktu sore, dan lain sebagainya. Mahasiswa juga sepertinya belum menganggap begitu penting PPII, sehingga ada kecenderungan bagi mereka untuk meremehkan. 61

Oleh karena itu semua komponen di kampus harus saling mendukung untuk maksimalnya pelaksanaan PPII ini. Sosialisasi sejak awal harus dilakukan kepada mahasiswa. Harus dibuat kesan bahwa semua mahasiswa urgen mengikuti kebijakan PPII ini. PPII harus di-include-kan kedalam kuliah reguler sehingga mahasiswa harus memprogramnya melalui siakad.

Dalam pelakasanaan PPII, memang antara satu fakultas dengan fakultas lain tidak sama; ada yang sudah berjalan lancar meski belum maskimal, ada yang jalan tersendat-sendat, dan ada yang tidak jalan sama sekali. Di Fakultas Tarbiyah dan Keguruan (FTK) berjalan lancar meski tidak maksimal dari sisi

60 Muhammad Thohir (Ketua P3M2 LPM UINSA), Wawancara pada 21 Juni 2017.

${ }^{61}$ Sulton Mas'ud (Koordinator Pendamping PPII FTK), Wawancara pada 4 Juli 2017. 
Ali Mas'ud, et. al.

masuknya mahasiswa, tetapi di beberapa fakultas yang lain ada yang tidak berjalan sama sekali karena mahsiswanya tidak mau kuliah PPII.62

Di sisi lain, kecenderungan materinya masih murni deskriptif seperti reguler, belum begitu berbau penalaran. Hal ini diperkuat oleh pandangan Fathurrohman, menurutnya, dalam PPII, kondisi sarpras kurang mendukung, sering ketika sudah waktunya masuk perkuliahan, ruangannya masih terpakai untuk kuliah reguler. Support pimpinan selama ini masih pada level kebijakan, belum pada level teknis operasional. Untuk teknis operasional diserahkan kepada kordinator di masing-masing fakultas. PPII yang jalan di FTK dan FEBI, yang lainnya tidak mulus jalannya. Di Fakultas Dakwah PPII tidak jalan. Seharusnya semua prodi harus mendapatkan, tidak hanya prodi umum, karena materinya bersifat kontekstual. Memang perlu placemen test untuk pemetaan, baik yang di prodi agama maupun prodi umum. ${ }^{63}$

Kendala tempat masih terjadi, sering dosen ketika mau ngajar tidak dapat kelas. Dari segi mahasiswa ada yang fokusnya tidak pada PPII. Oleh karena PPII diterapkan pada prodi umum saja, maka menjadikan mahasiswa tidak serius terpanggil karena yang lain tidak diwajibkan. Dari sisi dosen, banyak yang aktif, tapi kurang didukung oleh mahasiswa. Dari sisi kordinator, rata-rata kordinatornya berusaha menjalankan perannya dengan baik. Dari sisi materi, masih terkesan teoritis, kurang kental nuansa penalaran dan kontekstualnya. Usulan perbaikannya, harus dinalarkan dan dicarikan sisi kontekstualnya. ${ }^{64}$

Di sisi lain, menurut Muhaimin, kendala PPII adalah kurangnya sosialisasi sejak awal, semestinya sudah ada sosialisasi sejak masa orientasi mahasiswa baru, bahwa PPII ini wajib diikuti oleh mahasiswa prodi umum, bahkan kalau bisa semua mahasiswa di UINSA wajib mengikutinya karena materinya bersifat kontekstual dan prosesnya bersifat penalaran. Dari sisi dosen perlu ada pembinaan untuk penyamaan persepsi melalui kegiatan workshop atau pelatihan. Dari sisi pimpinan perlu suppoort yang lebih tinggi. Dari sisi sarpras terkadang terhambat oleh kuliah reguler. Ketika kuliah PPII sudah waktunya masuk kelas, ternyata kelas masih dipakai oleh kuliah reguler, sehingga terkadang harus menunggu dan keleleran di luar ruangan. Jadi memang harus dipersiapkan sarpras berupa ruang kelas. Dari sisi mahasiswa, semangatnya kurang maksimal karena ada yang sudah kelelahan kuliah mulai pagi, ada yang bertugas privat belajar, mengajar di TPQ dan sejenisnya, sehinggga satu kelas tidak pernah full mahasiswanya. Dari segi sanksi juga belum jelas sanksi untuk mahasiswa yang tidak mengikuti PPII.65

\footnotetext{
62 Nikmatul Khoiroh (Kordinator PPII FDK), Wawancara pada 12 Juli 2017.

${ }^{63}$ Fathurrohman (Dosen Pendamping PPII FTK), Wawancara pada 4 Juli 2017.

${ }^{64}$ Yunan Athoillah (Dosen Pendamping PPII FEBI), Wawancara pada 12 Juli 2017.

65 Muhaimin (Dosen Pendamping PPII SAINTEK), Wawancara pada 12 Juli 2017.
} 
Dengan demikian, banyak faktor yang masih menjadi kendala pelaksanaan PPII di UIN Sunan Ampel. Kendala-kendala ini perlu diselesaikan dengan melakukan hal-hal yang bisa mengatasinya. Misalnya, harus ada sosialisasi di awal kepada mahasiswa tentang wajibnya mengikuti PPII, perlu adanya persamaan persepsi di antara para dosen dalam hal filosofi dan metodologis pembelajaran PPII, perlu dukungan yang maskimal dari pimpinan, anggaran yang cukup dan memadai, dan hal-hal lain yang mendukung.

\section{G. Kesimpulan}

Program Penalaran Islam Indonesia (PPII) didesain sebagai program wajib yang harus diikuti oleh semua mahasiswa prodi umum di UIN Sunan Ampel. Cakupan materinya meliputi: Teologi Islam Kontekstual, Ekspresi Sufistik, Hukum Islam Kontektual, Metodologi Hukum Islam, dan Genealogi Peradaban Islam Indonesia. Program ini menjadi ciri khas UIN Sunan Ampel dan pembeda dari perguruan tinggi lain sebagai program yang menyertai peralihan status dari IAIN menjadi UIN Sunan Ampel. Tujuan PPII adalah menjadikan mahasiswa yang berperilaku Islam rahmatan lil 'alamin, ber-akhlaqul karimah, dan mampu mengintegrasikan nalar keislaman kedalam disiplin keilmuan yang ditempuhnya.

Melihat geliat gerakan keagamaan Islam yang radikal semakin berani menampilkan diri di publik, maka program penalaran Islam Indonesia menjadi sesuatu yang penting sebagai gerakan kontra radikalisme dan penguatan materi PAI yang rahmatan lil 'alamin. Materi-materi dalam PPII sinergis dengan materi PAI. Di PPII, materi-materinya dikaji dengan pendekatan penalaran atau dikentalkan dengan kajian rasional-empiris. Dalam epistemologi filsafat Islam, berarti seirama dengan pendekatan Burhani. Dengan demikian, eksistensi PPII di UIN Sunan Ampel sangat urgen.

Daya dukung pelaksanaan PPII antara lain adalah: adanya kebijakan pimpinan yang dikomandani oleh Warek 1, lalu turun ke Wadek 1, dan Prodiprodi serta berkoordinasi dengan LPM-P3M2 dan koordinator PPII di masingmasing fakultas. Materi yang kontekstual dan proses yang berbasis penalaran menjadi daya tarik dan daya dukung tersendiri bagi pelaksanaan PPII ini. Adanya sanksi tidak diberikannya sertifikat PPII bagi mereka yang tidak mengikuti/tidak lulus PPII juga menjadi daya dukung pelaksanaan PPII. Mengingat mahasiswa yang tidak punya sertifikat PPII tidak boleh maju ujian skripsi. Sehingga bagaimanapun mahasiswa prodi umum harus mengikuti dan lulus PPII.

Sementara kendala pelaksanaan PPII antara lain adalah: sosialisasi PPII yang tidak dilakukan sejak dini kepada mahasiswa baru, animo mahasiswa yang tidak begitu tinggi mengikuti PPII, sarana kelas yang terkadang masih dipakai kuliah reguler, mindset dosen pendamping yang belum sepenuhnya mengarah pada proses penalaran materi PPII, pelaksana PPII yang masih debatebale 
Ali Mas'ud, et. al.

(apakah masih di tangani LPM-P3M2 atau diserahkan ke unit lain), dan anggaran dana yang tidak dialokasikan sejak RKAKL 2017. Kendala-kendala ini masih menjadi penghambat pada pelaksanaan PPII yang maksimal.

\section{H. Referensi}

Fahmi, Muhammad. "Pengembangan Epistemologi Integrated Twin Towers di UIN Sunan Ampel Surabaya”. Episteme. Tulung Agung: PPs STAIN Tulung Agung, 2011.

Faizin, Moh. Pengembangan Epistemologi Twin Towers dalam Perspektif Filsafat IImu. Surabaya: Lemlit IAIN Sunan Ampel, 2012.

http://www.antaranews.com/berita/617040/peneliti-lp3es-islam-indonesiamenginspirasi-negara-lain (Diakses pada 23 Maret 2017).

http://www.uinsby.ac.id/news/id/12419/kembangkan-kurikulum-berbasispenalaran-islami (Diakses pada 23 Maret dan 5 Juli 2017).

Jabiry (Al), Muhammad Abed. Bunyah al-'Aql al-'Arabi. Beirut: Markaz ad-Dirasat Wahdah al-'Arabiyah, 2007.

LPM UINSA. Dokumen Laporan Kegiatan Program Penalaran Islam Indonesia (PPII) Tahun 2016. Surabaya: tp., 2017.

Mostofa, Imam. "Terorsisme: Antara Aksi dan Reaksi". Religio, Vol. 15 No.1. April, 2012.

Muslih, Mohammad. Filsafat Ilmu; Kajian Atas Asumsi Dasar, Paradigma dan Kerangka Teori Ilmu Pengetahuan. Yogyakarta: Belukar, 2004.

Nuh, Nuhrison M. "Faktor-faktor Penyebab Munculnya Faham/Gerakan Islam Radikal di Indonesia". Jurnal Multikultural dan Multi Religius. Vol. 8 No.31. September, 2009.

PMA RI No. 8 Tahun 2014 tentang Ortaker UIN Sunan Ampel Surabaya, Pasal 77, Ayat 1 (c).

Ridwan, Ahmad Hasan. Dasar-dasar Epistemologi Islam. Bandung: Pustaka Setia, 2011.

Rubaidi, A. Radikalisme Islam, Nahdlatul Ulama dan Masa Depan Moderatisme Islam di Indonesia. Surabaya: Pengurus Wilayah Nahdlatul Ulama Jawa Timur, 2007.

Saduloh, Uyoh. Pengantar Filsafat Pendidikan. Bandung: Alfabeta, 2009. 
Soleh, Khudori (Ed). Pemikiran Islam Kontemporer. Yogyakarta: Pustaka Pelajar, 2008.

. Filsafat Islam; Dari Klasik Hingga Kontemporer. Yogyakarta: Ar-Ruzz Media, 2013.

Suriasumantri, Jujun S. Filsafat Ilmu. Jakarta: Sinar Harapan, 1985.

Syaifuddin. "Komparasi Integrated Twin Tower dan Islamisasi Ilmu". JPAI. Surabaya: FTK UINSA, 2014.

Tim LPM UIN Sunan Ampel. Naskah Akademik Penyelenggaraan Program Penalaran Islam Indonesia (PPII) bagi Mahasiswa Prodi Umum di Lingkungan UIN Sunan Ampel. Surabaya: tp., 2015.

Tim UIN Sunan Ampel. Renstra Bisnis UIN Sunan Ampel 2014-2019. Surabaya: Uinsa Press, 2014.

. Konsep Integrated Twin Towers UINSA Surabaya. Dipresentasikan oleh Akh. Muzakki dalam Workshop Konsorsium Dosen UIN Sunan Ampel. Lawang, 10 November 2014.

\section{Informan}

Affan Ghoffar (Dosen UGM Yogyakarta), Genealogi Peradaban Islam Indonesia, Paparan dalam Workshop Peningkatan Kapasitas Dosen PPII, 11-13 Juli 2017, di Ruang Rektorat Lama UIN Sunan Ampel Surabaya.

Fathurrohman (Dosen Pendamping PPII FTK), Wawancara pada 4 Juli 2017.

Ibnu Anshori (Ketua LPM UINSA), Critical Review Integrated Twin Towers, Paparan dalam Workshop Peningkatan Kapasitas Dosen PPII, 11-13 Juli 2017, di Ruang Rektorat Lama UIN Sunan Ampel Surabaya.

, komentar dalam FGD Penyusunan Standar Penelitian dan Pengabdian kepada Masyarakat, Rabu, 23-8-2017, di Gedung Twin Towers A Lantai 9.

Karim (Dosen Pendamping PPII FISIP), Wawancara pada 12 Juli 2017.

Khoirun Ni'am (Ketua Pengembang Standar Mutu LPM UINSA), Review SIlabus PPII, Paparan dalam Workshop Peningkatan Kapasitas Dosen PPII, 11-13 Juli 2017, di Ruang Rektorat Lama UIN Sunan Ampel Surabaya.

, dalam sambutannya pada acara workshop peningkatan kapasitas dosen PPII, 11-13 Juli 2017 di ruang Rektorat lama UIN Sunan Ampel Surabaya.

Muhaimin (Dosen Pendamping PPII SAINTEK), Wawancara pada 12 Juli 2017. 
Ali Mas'ud, et. al.

Muhammad Thohir (Ketua P3M2 LPM UINSA), Wawancara pada 15 dan 21 Juni 2017.

Naha'i (Dosen IAI Ibrohimy Situbondo), Hukum Islam Kontekstual, Paparan dalam Workshop Peningkatan Kapasitas Dosen PPII, 11-13 Juli 2017, di Ruang Rektorat Lama UIN Sunan Ampel Surabaya.

Nikmatul Khoiroh (Kordinator PPII FDK), Wawancara pada 12 Juli 2017.

Sulton Mas'ud (Koordinator Pendamping PPII FTK), Wawancara pada 4 Juli 2017.

Syamsul Huda (Warek 1 UINSA), Wawancara pada 16 September 2017.

Yunan Athoillah (Dosen Pendamping PPII FEBI), Wawancara pada 12 Juli 2017. 